\title{
Byssus of the green-lipped mussel Perna viridis (Linnaeus) as a biomonitoring material for $\mathrm{Zn}$
}

\begin{abstract}
Recently, Yap et al. (2003) suggested that the byssus of the green-lipped mussel Perna viridis can be a biomonitoring material for $\mathrm{Zn}$ although further validation is required. In this work, we did a simple correlation study between Zn concentrations in the byssus (and soft tissue) and in different geochemical fractions of the sediment. A significant $(\mathrm{P}<0.01)$ Pearson's correlation coefficient $(\mathrm{R}=0.84)$ between the $\mathrm{Zn}$ concentrations in the byssus and soft tissue indicated that the $\mathrm{Zn}$ level in the byssus is highly correlated to its level in the soft tissue and that the byssus could act as an excretion route for $\mathrm{Zn}$. Higher R-values were found between the byssus-easily or freely, leachable and exchangeable, byssus-acid-reducible, byssusoxidizable-organic and byssus-nonresistant fractions of the sediment, and the byssus-Zn concentration in the total sediment when compared to those found between the soft tissue and the same geochemical fractions. This indicated that the byssus was more reflective of $\mathrm{Zn}$ contamination in the field environment than the soft tissue. Therefore, the data further support the use of the byssus as a biomonitoring material for $\mathrm{Zn}$ as was originally suggested by Yap et al.
\end{abstract}

Keyword: Biomonitoring material, Perna viridis, byssus, $\mathrm{Zn}$ 